\title{
$\mathrm{R} b-\mathrm{S}$ r 法
}

\author{
柴 田賢*
}

\section{Rb-Sr Method}

Ken SHibata

\section{I. はじめに}

$\mathrm{Rb}-\mathrm{Sr}$ 法は ${ }^{87} \mathrm{Rb}$ が $\beta$ 壊変して ${ }^{87} \mathrm{Sr}$ 亿変わるてとを利用して年代を測定する方法である。 $\mathrm{Rb}$ が放射能を

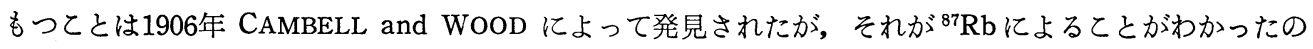
は1937年であった。そしてその直後から Rb-Sr 法による年代測定の可能性が検討され始めた。しかし $\mathrm{Rb}$ -Sr 法が実用化されたのは質量分析計の開発が進んだ1950年代のことである。小論では $\mathrm{Rb}-\mathrm{Sr}$ 法の原理, 試料, 問題点などについて解説する。

\section{II. 測定原理}

天然ておける $\mathrm{Rb}$ の同位体組成は ${ }^{85} \mathrm{Rb} 72.1654 \%,{ }^{87} \mathrm{Rb} 27.8346 \%$ であり, $\mathrm{Sr}$ のそれは ${ }^{88} \mathrm{Sr} 82.53 \%$, ${ }^{87} \mathrm{Sr} 7.04 \% ，{ }^{86} \mathrm{Sr} 9.87 \% ，{ }^{84} \mathrm{Sr} 0.56 \%$ である。ただし $\mathrm{Sr}$ 同位体組成は ${ }^{87} \mathrm{Rb}$ の壊変により加わる ${ }^{87} \mathrm{Sr}$ （放射性起源の ${ }^{87} \mathrm{Sr}$ という）のため一定ではない。年代測定の計算式を本法にあた屾ると,

$$
{ }^{87} \mathrm{Sr}={ }^{87} \mathrm{Sr}_{0}+{ }^{87} \mathrm{Rb}\left(\mathrm{e}^{\lambda \mathrm{t}}-1\right)
$$

となる。こてで ${ }^{87} \mathrm{Rb},{ }^{87} \mathrm{Sr}$ は岩石・鉱物中に現在存在する同位体の数, ${ }^{87} \mathrm{Sr}_{\text {。 }}$ は岩石・鈗物が生成された 時に存在した数, $\lambda$ は ${ }^{87} \mathrm{Rb}$ の壊変定数, $\mathrm{t}$ は生成されてからの年数である。こてで壊変に関係しない同位 体 ${ }^{86} \mathrm{Sr}$ で両辺を割れば，

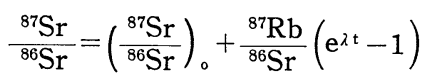

という式が得られる。てれがRb-Sr法による年代測定の計算式である。ての式によって年代を求めるにあ たっては，岩石・鉣物中の $\mathrm{Rb}, \mathrm{Sr}$ に関して出入りがなかった，すなわち閉鎖系 (closed system) であ るととが前提となっている。ての前提が成立しないと意味のある年代は求められない。

(2) 式の中の ${ }^{87} \mathrm{Sr} /{ }^{86} \mathrm{Sr}$ と ${ }^{87} \mathrm{Rb} /{ }^{86} \mathrm{Sr}$ は岩石・鉱物について直接測定される值である。 $\left.{ }^{87} \mathrm{Sr} /{ }^{86} \mathrm{Sr}\right) 。$ は ${ }^{87} \mathrm{Sr}$ ${ }^{86} \mathrm{Sr}$ 初生值（initial ${ }^{87} \mathrm{Sr} /{ }^{86} \mathrm{Sr}$ ratio）と呼ばれる值で, 岩石・鉣物ができた時に存在していた $\mathrm{Sr}$ の同位 体組成である。年代の計算においては $\left.{ }^{87} \mathrm{Sr} /{ }^{86} \mathrm{Sr}\right)$ 。の適当な值を仮定するか, 同じ起源で $\mathrm{Rb} / \mathrm{Sr}$ 比の異 なる 2 個以上の陚料を測定するてとにより年代と $\left.{ }^{87} \mathrm{Sr} /{ }^{86} \mathrm{Sr}\right)$ 。とを同時に求めるてとができる。とてろ で $\left({ }^{87} \mathrm{Sr} /{ }^{86} \mathrm{Sr}\right)$ 。は岩石成因を議論する際のきわめて重要な值であるてとがわかってきたため，最近では ほとんどの場合後者，すなわち 2 個以上の試料によって年代と $\left({ }^{87} \mathrm{Sr} /{ }^{86} \mathrm{Sr}\right)$ 。を求める手法がとられる。乙 の方法はアイソクロン法と呼ばれているが，(2) 式の ${ }^{87} \mathrm{Sr} /{ }^{86} \mathrm{Sr}$ と ${ }^{87} \mathrm{Rb} /{ }^{86} \mathrm{Sr}$ との関係を示す図（アイソク ロン図, 第 1 図）として表現すると理解しやすい。すなわち複数の岩石あるいは鈗物の測点によって作ら れる直線の勾配から年代が,また縦軸との交点から $\left({ }^{87} \mathrm{Sr} /{ }^{86} \mathrm{Sr}\right)$ 。が求められる。

第 1 図では同じ起源をもつ複数の岩石の全岩試料によって作られる直線（全岩アイソクロン）と，1個

* 工業技術院地質調査所 Geological Survey of Japan, Tsukuba. 


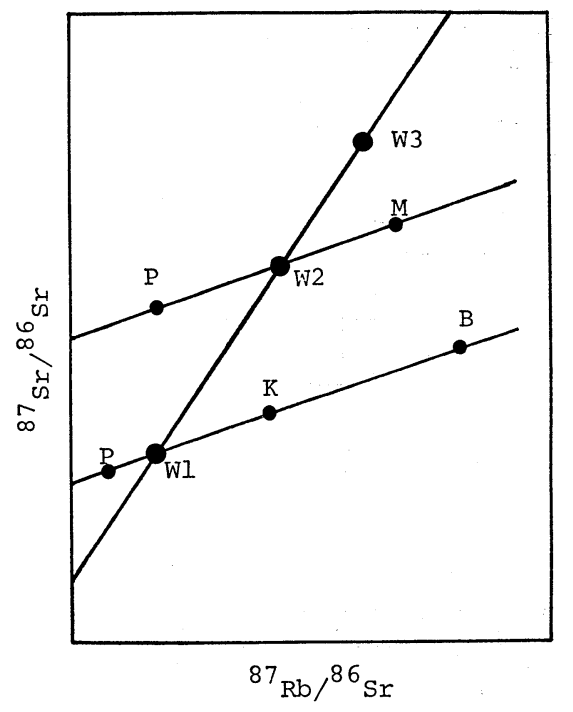

第 1 図 Rb-Srアイソクロン図

全岩 (W1, W2, W3) を結ぶ直線が 全岩アイソクロン, 鉱物 ( $\mathrm{B}, \mathrm{K}$, $\mathrm{P}$ とW1)を結ぶ直線が鉱物アイソク ロン。年代は直線の勾配から求めら れ, 縦軸との交点から ${ }^{87} \mathrm{Sr} /{ }^{86} \mathrm{Sr}$ 初生 值が求められる。

第 1 表 岩石・鉿物中の $\mathrm{Rb} \cdot \mathrm{Sr}$ 含有量

\begin{tabular}{lcc}
\hline \hline 試 料 & $\mathrm{Rb}(\mathrm{ppm})$ & $\mathrm{Sr}(\mathrm{ppm})$ \\
\hline 花崗岩 & 150 & 285 \\
花崗閃緑岩 & 120 & 450 \\
玄武岩 & 30 & 465 \\
頁岩 & 140 & 300 \\
レピドライト & $\sim 1 \%$ & $0-5$ \\
黒雲母 & $300-1000$ & $5-20$ \\
白雲母 & $200-500$ & $10-500$ \\
カリ長石 & $200-400$ & $150-2000$ \\
\hline
\end{tabular}

岩石のデータは平均值で TAYLOR (1965)

による。
の岩石の構成鉱物によって作られる直線（鉱物アイソク ロン）との二つを示してある。花崗岩が貫入後比較的急 速に冷却した場合は，全岩の測点と鉱物の測点は同じ直 線上に乗る。てれに対して, 花崗岩が貫入後, 何らかの 熱的事変, 例光ば変成作用を受けた場合は, 第 1 図のよ うに全岩アイソクロンが貫入の年代を, 鉱物アイソクロ ンが変成作用の年代を示す, という事も起りうる。全岩 アイソクロンについては後節で詳しく解説する。

\section{III. 試料と測定法}

\section{1. 試料}

$\mathrm{Rb}-\mathrm{Sr}$ 法による年代測定においては，一般的には $\mathrm{Rb}$ が多く Sr の少ない試料がよく利用される。第 1 表に主 な岩石及び造岩鉣物の $\mathrm{Rb}$ と $\mathrm{Sr}$ の含有量を示した。鉣 物では雲母類, カリ長石がよく用いられるが, ての場合 でも，鈗物と全岩との両方を測定して，いわゆる鉱物ア イソクロンから年代を求めるのが一般的である。特にカ リ長石は $\mathrm{Rb} / \mathrm{Sr}$ 比がそれほど高くないので全岩と組み合 わせなければ正確な年代は得られない。全岩試料の場合 はなるべく $\mathrm{Rb} / \mathrm{Sr}$ 比にばらつきのある試料を選び, 誤差 を少くするため 3 個以上使用するてとが望ましい。全岩 アイソクロン法は火成岩, 特に $\mathrm{Rb} / \mathrm{Sr}$ 比の比較的大きい 花崗岩に対して最も広く利用されるが, 最近では $\mathrm{Rb} / \mathrm{Sr}$ 比の小さい苦鉄質岩石にも利用の範囲が広がっている。 火山岩については珪長質岩石が主な対象となる。 $\mathrm{Rb} / \mathrm{Sr}$ 法は変成岩にも広く利用されており, 前述のよう亿原岩 や変成作用の年代に関して重要な情報を提供してくれる。 一方堆積岩については, 特に地質年代尺度に関連して堆 積年代を求める目的で，測定が試みられてきた。

2. 測定法と測定䛊差

$\mathrm{Rb}-\mathrm{Sr}$ 法による測定法は, $\mathrm{Rb}$ と $\mathrm{Sr}$ の定量と ${ }^{87} \mathrm{Sr} /{ }^{86} \mathrm{Sr}$ 比の測定に分けられる。 $\mathrm{Rb}$ と $\mathrm{Sr}$ の定量は ${ }^{84} \mathrm{Sr},{ }^{87} \mathrm{Rb}$ を スパイクとして用いる同位体希釉法が標準的な方法であ るが, 単光X線分析による定量も比較的よく用いられる。 分析法については兼岡（1976），加々美ほか（1982）な どに詳しいので,ててではふれない。

同位体希釈法における測定精度は $\mathrm{Rb}$ で 1 2\%, Sr で 0.5\% 程度である。一方 ${ }^{87} \mathrm{Sr} /{ }^{86} \mathrm{Sr}$ 比の方は, 最近質量分析計の精度が著しく向上したため $0.01 \%$ 以下の誤差での測定が可能となった。第 2 図に地質調 查所における $\mathrm{Sr}$ 同位体比用標準試料 $\mathrm{E} \& \mathrm{~A} の{ }^{87} \mathrm{Sr} /{ }^{86} \mathrm{Sr}$ 比の最近における 測定例をヒストグラムで示した。 この場合の測定結果は正規分布に近く，200回の平均で $0.70808 \pm 0.00011 （ 1 \sigma)$ で標準偏差は $0.016 \%$ である。しかし同位体比の測定においては，一般䛊差を平均值の標準誤差の 2 倍（two standard errors 


$$
\begin{gathered}
\mathrm{Av},=0.70808 \pm 0.00011(1 \sigma) \\
(\mathrm{N}=200)
\end{gathered}
$$

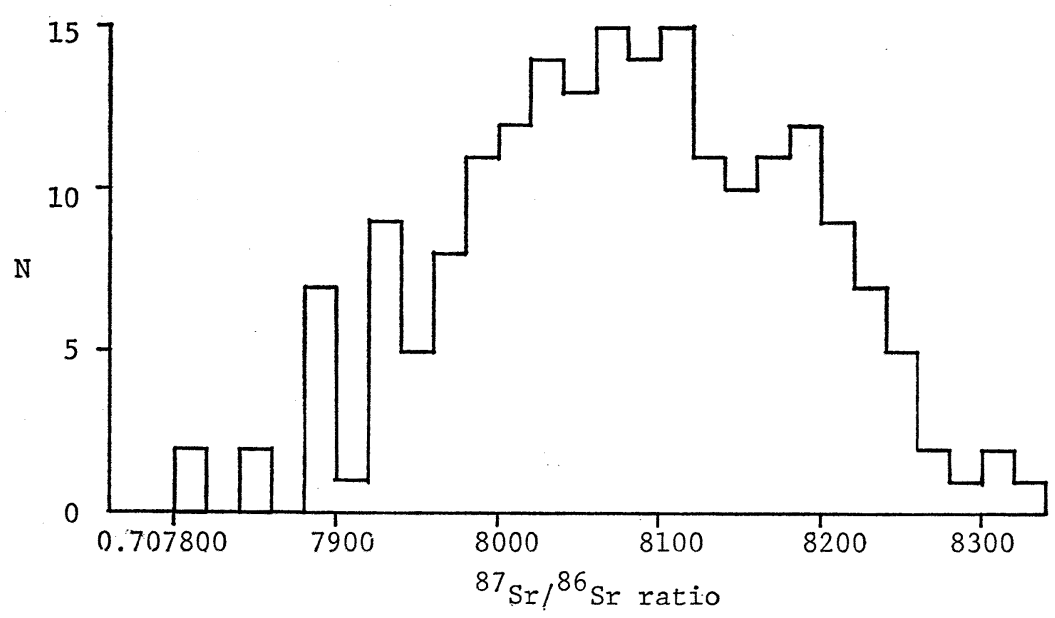

第 2 図標準試料 $\mathrm{E} \& \mathrm{~A} の^{87} \mathrm{Sr} /{ }^{86} \mathrm{Sr}$ 比測定結果

on the mean : $2 \sigma_{\mathrm{m}}$ 又は $2 \sigma$ mean ) という值で示すととが多く, との表現に従えば上記の標準偏差の $\frac{2}{\sqrt{200}}$ 倍すなわち $0.70808 \pm 0.00002$ と小さくなる。また E \&Aの長期間にわたるくり返し測定の結果は, $0.708083 \pm 0.000017$ ( $1 \sigma$, 測定回数60) である。なおこの E\&Aは NBS 987 と共に Sr 同位体比測定にお ける質量分析計の校正に使用される標準試料で, 論文中にその值が記載され同位体比の相互比較のための 重要な規準値となっている。

$\mathrm{Rb}-\mathrm{Sr}$ 法による年代值の誤差は, 上にのべた測定誤差が関係してくる。 $\mathrm{Rb} / \mathrm{Sr}$ 比が30以上の黒雲母につ いては，年代が $10 \mathrm{Ma}$ より古ければ，誤差（1 $\sigma$ ) は土 $3 \%$ である。ての雲母の年代が $1 \mathrm{Ma}$ としても， その誤差は 10\% 程度である。多数の試料を用いてアイソクロン法で年代を求める場合には, MCINTYRE et al. (1966) や YORK (1969) らか開発した最小二乗法を用いて年代と誤差か計算される。ての方法は 個々の測点 $\left({ }^{87} \mathrm{Sr} /{ }^{86} \mathrm{Sr},{ }^{87} \mathrm{Rb} /{ }^{86} \mathrm{Sr}\right)$ 飞伴う測定誤差の逆数の 2 乗を重みとして, 測点からのずれが最小に なるような直線（アイソクロン）を求める方法であり，複雑な計算を必要とするので，コンピューターが 利用される。求められたアイソクロンからの測点のずれが，測定誤差の範囲内にあるかどうかの判定のた めに, MSWD (Mean Square of Weighted Deviates, 加重偏差の 2 乗の平均) という值か計算されて いる。この值がある一定の基準值（10前後の測定数の場合は 2.5）をてす場合には, 測定誤差以外の誤差 が含まれるものと判断される。そしてての直線のととをエラクロン（errorchron）と呼ぶてとがある。 ての原因は測点の中に起源（年代，あるいは初生值）を異にするものが混じっているためであり，それを 除いて再計算し正しい年代を求めるというととが行われる。

3. 壊変定数

測定精度には直接関係はないが, 壊変定数 $\lambda$ の問題は重要である。 ${ }^{87} \mathrm{Rb} の \lambda$ は現在 $1.42 \times 10^{-11} /$ 年が広 く使用されている。乙れは1977年に IUGS 年代学小委員会（STEIGER and JÄGER 1977） が統一使用の ために勧告した值である。しかしそれ以前は $1.39 \times 10^{-11}$ 年と $1.47 \times 10^{-11} /$ 年という 2 つかなり異なっ た值が使用されていた。従って古い定数による年代值を新しい定数による值と比較する場合には，一定の 係数をける必要がある。すなわち1.39の場合は $0.9789 を ， 1.47$ の場合は1.035をかけなければならない。 


\section{IV. $\mathrm{Rb}-\mathrm{Sr}$ 全岩法の問題点}

$\mathrm{Rb}-\mathrm{Sr}$ 全岩アイソクロン法により意味のある年代を求めるためには，次の点が満されなければならない。 1. 一組の岩石試料が同じ ${ }^{87} \mathrm{Sr} /{ }^{86} \mathrm{Sr}$ 初生值と年代をもつ。

2. $\mathrm{Rb}, \mathrm{Sr}$ 比に関して閉鎖系であったてと。

3. $\mathrm{Rb} / \mathrm{Sr}$ 亿適当なばらつきがあるとと。

とてろで，1 と 3 とはあい反する条件である。すなわち Rb/Sr比にある程度のばらつきをもたすために は広い範囲を対象としなければならず，そうすると初生值が同じという条件が満たされない場合も生じ得 る。最近大きな花崗岩体では場所によって初生值が異なるというととが，しばしば発見されるようになっ た（例 RODDICK and COMPSTON 1976）。大きな岩体ではSr同位体の完全な均質化が起るということの 方が，むしろ考えにくいとされるようになったが，てのととは ${ }^{87} \mathrm{Sr} /{ }^{86} \mathrm{Sr}$ 同位体比の測定精度が格段に向 上したため，その現象が確認された結果といえる。

それでは具体的にはどのような基準で全岩試料を採取したらよいか，についてのべる。まずできるだけ せまい範囲（たとえば大きな露頭）で $\mathrm{Rb} / \mathrm{Sr}$ 比に差が出そうな試料を選ぶ。採取する試料の量は，岩質， 粒度によって異なるが, 一応の目安として $2 \sim 3 \mathrm{~kg}$ と考えてよい。その根拠は, 岩石生成後の冷却の過 程あるいは後の変成作用による温度上昇の際に, たと元放射性起源の ${ }^{87} \mathrm{Sr}$ の移動か起っても鈗物間 $(\mathrm{mm}$ 単位)での現象であり, $10 \mathrm{~cm}$ 角程度の全岩試料の単位では閉鎖系とみなされる, という判断にもとづい ている。これは丁度第 1 図における全岩及び鉱物アイソクロンがそれぞれ花崗岩生成，変成作用の年代に 対応する場合にあてはまる。

全岩試料では試料の調製法も重要であり,できるだけ全岩試料を代表しうる均質な細粉試料を作らなけ ればならない。そのためには岩石試料全部を 200 メッシュ以下に粉砕・混合するのが理想的であるが, 多 数の陚料を取り扱う場合には手間の点で問題がある。簡単にはジョークラッシャーで全部を〜 $5 \mathrm{~mm}$ 以下 にくだき, 縮分器でていねいに量をへらし, 最後に少なくとも100g以上を細粉するという方法がよくとら れる。

変成岩については原岩の年代や初生值が同じであるという条件を必ずしも満たしていないとと, 変成作 用の程度と均質化の関係という点で全岩アイイソクロンの意味は複雑である。かつては角閃岩相以上の高度 の変成作用の元ではSr同位体は均質化し, 從ってアイソクロンは変成作用の年代を示すという考方方が支 配的であった。しかし最近では大規模な均質化は起りにくいという考方方が有力になってきている。たと えば世界最古の岩石である西グリーンランドのアミッォク片麻岩は, $2700 〜 2800 \mathrm{Ma}$ の角閃岩相の変成作 用をうけているにもかかわらず $3800 \mathrm{Ma}$ の全岩年代を示す。またグラニュライト相の変成岩でる均質化は 起らず原岩の年代を示す例も報告されている。一方層状変成岩の研究からは，cm オーダーでの均質化が 起り, 変成作用の年代を示すとともよく知られている。: 変成岩の全岩アイソクロンが変成作用の年代を示 すかどうかの判断の一つとして, ${ }^{87} \mathrm{Sr} /{ }^{86} \mathrm{Sr}$ 初生值が参考になる。初生值がかなり高ければ変成岩はアイソ クロンが示す年代より以前の地殸物質としての歴史をもつてとを物語り, 変成年代であるといえる。しか し初生值が高くなるととはむしろ少ないので, ての值による判定は一般には困難である。一方全岩年代が 鉱物年代に等しい場合は，変成年代である可能性が高い。てれは結晶片岩などで時々みられるケースであ る。

いずれにせよ変成岩の全岩アイソクロン年代の解积については, 年代值だけで判断するてとは困難であ り, 岩質, 変成度, 初生值などの情報を考慮して総合的に判断する必要がある。最近では $\mathrm{Nd}$ 同位体比も 合わせて測定されるようになり成因を考える上での重要なデータとなっている。

火山岩については, たとえ全岩武料であっても一般に変成作用等による熱的影響を受けやすいてとが知 られている。てれは放射性起源の ${ }^{87} \mathrm{Sr}$ が細粒の基質から逃げ易いためと考元られ，特に $\mathrm{Rb} / \mathrm{Sr}$ 比の大きい 
珪長質岩石について，予想より若い年代值を示すととがある。雲母類の年代の方が全岩アイソクロン年代 よりも古いという例も報告されている。また, 火山碎膺岩については変質を受け易いという点と, 外来岩 片の混入という問題もある。てれらのてとから火山岩の $\mathrm{Rb}-\mathrm{Sr}$ 全岩年代の測定においては, 試料の選択と 結果の解釈について特に慎重な配慮が必要である。

堆積岩中の自成鈗物である海緑石は，堆積年代を直接測定できるという点で，特に年代尺度作成のため に重要である。しかし海緑石の Rb-Sr年代測定の結果は予想される年代よりも10２0\%低いとされてきた， 最近の研究結果においても Rb-Sr 年代は $\mathrm{K}-\mathrm{Ar}$ 年代よりも信頼性が低い。そてで海緑石の年代は結晶度の よい，K含量の高い（7\%以上）試料について K-Ar 法と Rb-Sr 法とを併用するてとが望ましいとされて いる（ODIN 1982）。堆積岩の Rb-Sr 全岩年代の測定については，主に頁岩，粘土岩などの細粒岩につい て研究が行われ，アイソクロン年代が求められた例も多い。ただその年代がいかなる地質現象の年代を示 すかについては, 古い砕屏物や同位体均質化などの問題がからみ, 解秎が困難な場合が多い。SHIBATA and MIZUTANI（1982）は化石で時代のわかった美濃帯の珪質頁岩・チャートの年代測定結果から，ア イソクロン年代は堆積後の化学的な続成作用がほぼ終了した年代を示すものであろうと考えた。ての種の 研究は今後の発展が大いに期待される。なお，わが国における Rb-Sr年代研究については，柴田（1985） にまとめられているので参照されたい。

\section{v. あとがき}

$\mathrm{Rb}-\mathrm{Sr}$ 年代測定における技術的問題, 特にSr同位体比の測定については, 現在の形の質量分析計の改良 という点からみれば, ほぼ限界に達していると思われる。ただその限界に挑戦するという点で, 100 万年 以下の若い岩石の年代測定は盛んになるものと思われる。しかし Rb-Sr法は試料の問題, 例えば全岩試料 にわける異質性の程度や代表試料の抽出法などが年代測定において考慮しなければならない重要な問題と なる。逆にての分野の研究は岩石の成因や $\mathrm{Rb} ・ \mathrm{Sr}$ の移動という興味あるテーマにも関係している。今後 $\mathrm{Rb}-\mathrm{Sr}$ 全岩法はよりきめの細かい研究へと進展してゆくであろう。そして Nd 同位体の研究もあわせて試 みられるようになるであろう。

\section{文献}

加々美寛雄・岡野 修・須藤 宏・本間弘次（1982）：MAT 260亿よる $\mathrm{Sr}$ 同位体比測定及び $\mathrm{Rb} ・ \mathrm{Sr}$ 定 量分析. 岡山大温研報告, No. 52, 51-70.

兼岡一郎 (1976) : 地球年代学. 新実験化学講座, 10 (宇宙地球化学), 352-376.

MCINTYRE, G. A., BROOKS, C., Compston, W. and TUREK, A. (1966) : The statistical assessment of $\mathrm{Rb}-\mathrm{Sr}$ isochrons. J. Geophys. Res., 71, 5459-5468.

ODIN, G. S. (1982) : How to measure glaucony ages, In Numerical Dating in Stratigraphy, ODIN, G. S. (ed.,), Wiley, 387-403.

RODDICK, J. C. and COMPSTON, W. (1976) : Radiometric evidence for the age of emplacement and cooling of the Murrumbidgee Batholith. Jour. Geol. Soc. Australia, 23, 223-233.

柴田 賢（1985）：地質年代学における技術的進歩と日本における年代学的研究. 地質学論集, No. 25 , 391-405.

ShibATA, K. and MizUTANI, S (1982): Isotopic ages of Jurassic siliceous shale and Triassic bedded chert in Unuma, Central Japan. Geochem. Jour., 16, 213-223.

STEIGER, R. H. and JÄGER, E. (1977) : Subcommission on Geochronology : convention on the use of decay constants in geo- and cosmochronology. Earth Planet. Sci. Lett., 36, 359-362.

TAYLOR, S. R. (1965) : The application of trace element data to problems in petrology. In Physics and Chemistry of the Earth, Ahrens, L. A., PrESS, F., RUNCORN, S. K. and UREY, C. (eds.), Pergamon, 133-214.

YORK, D. (1969) : Least-squares fitting of a straight line with correlated errors. Earth Planet. Sci. Lett., 5, 320-324. 